\title{
ANALISIS PENGARUH BENTUK PROFIL TERSUSUN TERHADAP GAYA TEKAN PADA BAJA CANAI DINGIN DENGAN METODE ELEMEN HINGGA
}

\author{
Dero Andika ${ }^{1}$ dan Leo S. Tedianto ${ }^{2}$ \\ ${ }^{1}$ Program Studi Sarjana Teknik Sipil, Universitas Tarumanagara, Jl. Letjen S. Parman No.1 Jakarta \\ dero.325170072@stu.untar.ac.id \\ ${ }^{2}$ Program Studi Sarjana Teknik Sipil, Universitas Tarumanagara, Jl. Letjen S. Parman No.1 Jakarta \\ leotedi@ft.untar.ac.id
}

\begin{abstract}
In this modern world of construction, the usage of cold formed steel has developed and started to widely used for main structures such as columns and beams. Cold formed steel is manufactured by folding a thin steel plate into desired model. This result in its relatively large width-to-thickness ratio. Therefore, the use of cold formed steel as a column to withstand compressive axial force is deemed ineffective because of its vulnerability to buckling failure. One of the ways to overcome buckling failure is to use built-up profile. The profiles in which are examined are $R$ and $2 R$ with the effective length of 2950mm and variated between fixed-fixed roller end and pinned-roller end. Whereas $R$ profile is the combination of $C$ and U channel. MIDAS FEA is a finite element-based software which is used to model the desired structures in this study. The results of the study showed calculations using MIDAS FEA are closer to the theoretical calculations of AISI S100-07 on the fixed-fixed roller end. The 2R profile provided $250 \%$ greater compressive strength value compared to the $R$ profile. The fixed-fixed roller end resulted in $147 \%$ higher compressive strength compared to the pinned-roller end. The results using MIDAS FEA resulted in closer results to AISI S100-07.
\end{abstract}

Keywords: cold formed steel; built-up; compressive strength; finite element method; MIDAS FEA

\begin{abstract}
ABSTRAK
Pada dunia konstruksi modern penggunaan baja canai dingin sudah berkembang dan penggunaannya mulai banyak digunakan untuk struktur utama seperti kolom dan balok. Pembuatan baja canai dingin yang ditekuk dari pelat baja membuat ketebalannya relatif tipis jika dibandingkan dengan lebar ataupun tinggi nya. Akibatnya penggunaan baja canai dingin sebagai kolom yang dominan menahan gaya aksial tekan dirasa tidak efektif karena sifatnya yang rentan terhadap kegagalan tekuk. Salah satu cara untuk mengatasi kegagalan tekuk adalah menggunakan profil tersusun. Pada penelitian ini diuji adalah profil $\mathrm{R}$ dan $2 \mathrm{R}$ dengan panjang $2950 \mathrm{~mm}$ yang disertai dengan variasi peletakan sendi-rol dan jepit-jepit rol pada kedua ujungnya. Dimana profil $\mathrm{R}$ adalah profil gabungan antara profil $\mathrm{C}$ dan porfil U. Penelitian ini menggunakan program metode elemen hingga MIDAS FEA untuk memodelkan struktur yang diinginkan. Profil yang. Hasil analisis penelitian ini didapatkan bahwa perhitungan dengan program MIDAS FEA lebih mendekati perhitungan teoritis AISI S100-07 pada profil jepit-jepit rol. Untuk profil tersusun 2R memberikan kuat tekan lebih besar 250\% dibandingkan dengan profil R. Peletakan jepit-jepit rol mengakibatkan kuat tekan baja canai dingin lebih tinggi 147\% dibandingkan dengan peletakan sendi-rol. Pemodelan menggunakan MIDAS FEA memberikan hasil lebih mendekati perhitungan teoritis dengan AISI S100-07.
\end{abstract}

Kata kunci: Baja canai dingin; profil tersusun; kuat tekan; metode elemen hingga; MIDAS FEA

\section{PENDAHULUAN}

Material baja untuk konstruksi pada dunia konstruksi modern sudah tidak asing lagi. Sifat dari baja yang seragam, kuat terhadap tarik, tidak mudah terbakar, tidak mudah menyusut, tidak menyerap kelembapan, serta tahan terhadap rayap dapat menggantikan material kayu yang selama ini digunakan pada konstruksi bangunan konvensional (Dewobroto, 2015). Jenis baja yang umum digunakan pada konstruksi adalah baja gilas panas (hot roll) dan baja canai dingin (cold formed). Baja canai dingin adalah pelat baja yang dibentuk atau ditekuk pada suhu ruangan untuk membentuk suatu bentuk profil tertentu dengan toleransi dimensi yang lebih presisi (Yu dan LaBoube, 2010).

Bentuk penampang baja canai dingin biasanya berbentuk $\mathrm{C}(\mathrm{CNP})$ atau yang biasa dikenal dengan lipped channel. Penggunaan baja canai dingin sebagai material struktur bangunan yang paling umum ditemui adalah pada kuda- 
kuda rangka atap. Baja canai dingin digunakan karena beratnya yang ringan jika dibandingkan dengan baja gilas panas, sehingga beban pada atap tidak terlalu besar. Akan tetapi pada dunia konstruksi baja modern, penggunaan bajai canai dingin untuk konstruksi mulai berkembang dan sekarang sudah mulai digunakan sebagai struktur utama seperti kolom, dan balok. Umumnya kolom baja canai dingin terbuat dari profil tersusun 2 buah profil $\mathrm{C}$, atau gabungan antara profil $\mathrm{C}$ dan profil U canai dingin yang biasanya digabung dengan baut atau sekrup (self drilling screw). Profil tersusun ini juga memiliki kelebihan jika dibandingkan dengan profil tunggal, yaitu dapat memiliki bentang yang lebih panjang, kemampuan untuk menahan beban yang lebih besar, serta ketahanan terhadap torsi yang lebih besar dikarenakan profil tersusun biasanya merupakan profil simetris yang dapat mengabaikan eksentrisitas dari penampang tersebut (Li dkk, 2014).

Eksperimen yang dilakukan oleh Rodrigues dkk. dari University of Coimbra, Portugal pada tahun 2016 untuk mencari tentang pengaruh dari bentuk penampang terhadap gaya tekan maksimum $\left(\mathrm{P}_{\max }\right)$ yang dapat ditahan oleh sebuah kolom baja canai dingin yang diberikan gaya tekan. Hasil eksperimen tersebut di menunjukan bahwa baja canai dingin dengan profil $2 \mathrm{R}$ dapat menahan gaya tekan lebih besar dibandingkan dengan profil lainnya dengan perbedaan hampir 300\% dari profil tersusun I. Pada eksperimen tersebut dicoba beberapa bentuk profil baja canai dingin, diantaranya adalah profil $\mathrm{C}$, profil tersusun $\mathrm{I}$, profil tersusun $\mathrm{R}$, serta profil tersusun $2 \mathrm{R}$. Dan hasil dari eksperimen dibandingkan dengan perhitungan yang diprediksi dengan menggunakan rumus pada AISI S100-07 (Rodrigues dkk, 2016.).

\section{Lebar efektif lip atau pengaku}

Lebar efektif $\left(b_{e}\right)$ dari lip elemen dengan pengaku yang mengalami tekan merata harus ditentukan dari:

- Untuk $\lambda \leq 0.673$

$$
\mathrm{b}_{\mathrm{e}}=\mathrm{b}
$$

- $\quad$ Untuk $\lambda \geq 0.673$

$$
\begin{gathered}
\mathrm{b}_{\mathrm{e}}=\rho \mathrm{b} \\
\rho=\frac{1-\frac{0,22}{\lambda}}{\lambda} \leq 1 \\
\lambda=\sqrt{\frac{\mathrm{f}^{*}}{\mathrm{fr}_{\mathrm{cr}}}} \\
\left.\mathrm{f}=\frac{0,578}{\Psi+0,34} \frac{\mathrm{k} \times \pi^{2} \times \mathrm{E}}{12\left(1-\mathrm{v}^{2}\right)}\right\}\left(\frac{\mathrm{t}}{\mathrm{d}}\right)^{2} \\
\Psi=\frac{\mathrm{f}_{1}}{\mathrm{f}_{2}}
\end{gathered}
$$

dengan $\rho=$ faktor lebar efektif, $\lambda=$ rasio kelangsingan, $\mathrm{f}^{*}=$ tegangan desain berdasarkan lebar efektif, $\mathrm{f}_{\mathrm{cr}}=$ tegangan tekuk elastis pelat, $\mathrm{k}=$ koefisien tekuk, $\Psi=$ rasio tegangan, $\mathrm{E}=$ modulus elastisitas young $\left(2 \times 10^{5} \mathrm{MPa}\right), \mathrm{t}=$ tebal profil

$\mathrm{f}_{1}$ dan $\mathrm{f}_{2}$ merupakan tegangan yang didasarkan pada penampang bruto dimana $\mathrm{f}_{1}$ dalam tekan dan $\mathrm{f}_{2}$ dapat berupa tarik atau tekan. Dalam kasus dimana $f_{1}$ dan $f_{2}$ keduanya dalam $f_{1} \geq f_{2}$.

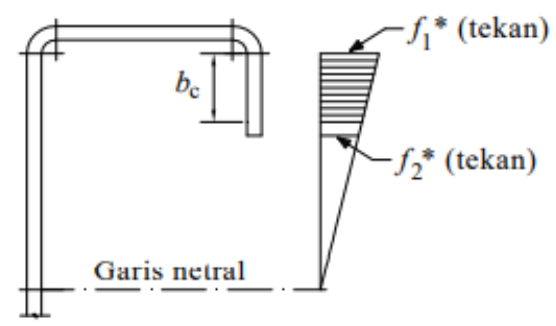

Gambar 1. Diagram $f_{1}$ dan $f_{2}$ (Sumber: SNI 7971:2013) 


\section{Lebar efektif flange atau sayap}

Lebar efektif $\left(b_{\mathrm{e}}\right)$ dari flange elemen dengan pengaku yang mengalami tekan merata harus ditentukan dari:

$$
S=1,28 \sqrt{\frac{E}{f}}
$$

- $\quad$ Untuk $\frac{b}{t} \leq 0,328 S$, dimana

$$
\begin{gathered}
\mathrm{b}_{\mathrm{e}}=\mathrm{b} \\
\mathrm{b}_{1}=\mathrm{b}_{2}=\frac{\mathrm{b}}{2} \\
\mathrm{~d}_{\mathrm{s}}=\mathrm{d}_{\mathrm{se}} \\
\mathrm{A}_{\mathrm{s}}=\mathrm{A}_{\mathrm{se}}
\end{gathered}
$$

- $\quad$ Untuk $\frac{b}{t}>0,328 S$

$$
\begin{gathered}
b_{1}=\frac{b e}{2}\left(\frac{I_{s}}{I_{a}}\right) \\
b_{2}=b_{e}-b_{1} \\
d_{s}=d_{s e}\left(\frac{I_{s}}{I_{a}}\right) \\
A_{s}=A_{s e}\left(\frac{I_{s}}{I_{a}}\right) \\
I_{a}=399 t^{4}\left(\frac{b / t}{S}-0.328\right)^{3} \leq t^{4}\left(115 \frac{b / t}{S}+5\right) \\
I_{s}=\frac{d^{3} t \operatorname{Sin}^{2} \theta}{12} \leq I_{a}
\end{gathered}
$$

\begin{tabular}{|c|c|c|c|}
\hline \multicolumn{2}{|c|}{ Pengaku tepi lip sederhana $\left(140^{\circ} \geq \theta \geq 40^{\circ}\right)$} & \multirow[b]{2}{*}{ Pengaku tipe yang lain } & \\
\hline$d_{1} /_{b} \leq 0,25$ & $0,25 \leq d_{1} / b \leq 0,8$ & & \\
\hline $3,57\left(\frac{\mathrm{I}_{\mathrm{a}}}{\mathrm{I}_{\mathrm{s}}}\right)^{\mathrm{n}}+0,43 \leq 4$ & $\left(4,82-\frac{5 d_{1}}{b}\right)\left(\frac{I_{s}}{I_{a}}\right)^{n}+0,43 \leq 4$ & $3,57\left(\frac{I_{s}}{I_{a}}\right)^{n}+0,43 \leq 4$ & \\
\hline & $\mathrm{f}_{\mathrm{cr}}=\left\{\frac{\mathrm{k} \times \pi^{2} \times \mathrm{E}}{12\left(1-\mathrm{v}^{2}\right)}\right\}\left(\frac{\mathrm{t}}{\mathrm{b}}\right)^{2}$ & & $(20)$ \\
\hline & $\lambda=\sqrt{\frac{\mathrm{f}^{*}}{\mathrm{f}_{\mathrm{cr}}}}$ & & $(21)$ \\
\hline & $\rho=\frac{1-\frac{0,22}{\lambda}}{\lambda} \leq 1$ & & $(22)$ \\
\hline Jika, $\lambda \leq 0.673$ & $b_{e}=b$ & & $(23)$ \\
\hline Jika, $\lambda>0.673$ & $\mathrm{~b}_{\mathrm{e}}=\rho \mathrm{b}$ & & (24) \\
\hline
\end{tabular}

Jika $I_{s} \geq I_{a}$, maka $I_{s}=I_{a}$

$$
\mathrm{n}=0,582-\frac{\mathrm{b} / \mathrm{t}}{4 \mathrm{~S}} \geq \frac{1}{3}
$$

Tabel 1. Nilai koefisien tekuk pelat (Sumber: SNI 7971:2013)

Koefisien tekuk pelat $(k)$ 


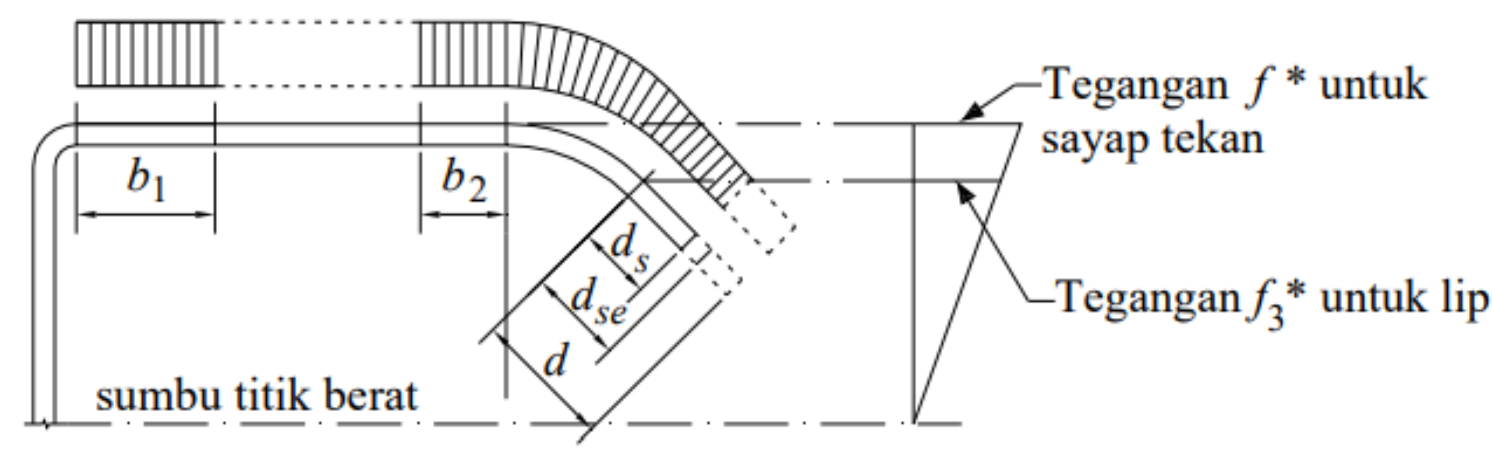

Gambar 2. Lokasi $b_{1}, b_{2}$, dan $d_{s}$ (Sumber: SNI 7971:2013)

dengan $f=f_{n}$ dalam menentukan kekuatan kemudian saat kondisi layan merupakan tegangan yang terjadi pada penampang efektif $\left(\mathrm{f}_{\mathrm{d}}\right), \mathrm{b}=$ lebar datar seperti yang ditunjukkan pada Gambar $2, \mathrm{I}_{\mathrm{a}}=$ inersia yang memadai, $\mathrm{d}_{\mathrm{se}}=$ lebar efektif pengaku, $\mathrm{I}_{\mathrm{s}}=$ inersia pengaku, $\mathrm{k}=$ faktor tekuk pelat

\section{Lebar efektif web atau badan}

Lebar efektif $\left(b_{\mathrm{e}}\right)$ dari web elemen dengan pengaku yang mengalami tekan merata harus ditentukan dari:

$$
\begin{gathered}
\mathrm{f}_{\mathrm{cr}}=\left\{\frac{\mathrm{k} \times \pi^{2} \times \mathrm{E}}{12\left(1-\mathrm{v}^{2}\right)}\right\}\left(\frac{\mathrm{t}}{\mathrm{H}}\right)^{2} \\
\lambda=\sqrt{\frac{\mathrm{f}_{\mathrm{f}}^{\mathrm{f}}}{\mathrm{fr}^{*}}} \\
\rho=\frac{1-\frac{0,22}{\lambda}}{\lambda} \leq 1
\end{gathered}
$$

Untuk $\lambda \leq 0.673$

$$
\mathrm{b}_{\mathrm{e}}=\mathrm{b}
$$

Untuk $\lambda \geq 0.673$

$$
b_{e}=\rho b
$$

dengan $\rho=$ faktor lebar efektif, $\lambda=$ rasio kelangsingan, $\mathrm{f}^{*}=$ tegangan desain berdasarkan lebar efektif, $\mathrm{f}_{\mathrm{cr}}=$ tegangan tekuk elastis pelat, $\mathrm{k}=$ koefisien tekuk, $\mathrm{E}=$ modulus elastisitas young $\left(2 \times 10^{5} \mathrm{MPa}\right), \mathrm{t}=$ tebal profil.

\section{Batang tekan}

Berdasarkan pada SNI 7971:2013 dan AISI S100-07, Komponen struktur dengan resultan semua beban yang bekerja padanya berupa gaya aksial yang melalui titik berat penampang efektif yang dihitung pada tegangan kirtis $\left(f_{n}\right)$. Gaya aksial tekan desain $\left(\mathrm{N}^{*}\right)$ harus memenuhi syarat berikut :

a) $\mathrm{N}^{*} \leq \Phi_{\mathrm{c}} \mathrm{N}_{\mathrm{s}}$

b) $\mathrm{N}^{*} \leq \Phi_{\mathrm{c}} \mathrm{N}_{\mathrm{c}}$

Dengan $\Phi_{c}=$ faktor reduksi kapasitas untuk komponen tekan (0,85 LRFD), $\mathrm{N}_{\mathrm{s}}=$ kapasitas penampang nominal dari komponen struktur dalam tekan $\left(\mathrm{A}_{\mathrm{ey}} \mathrm{f}_{\mathrm{y}}\right), \mathrm{A}_{\mathrm{ey}}=$ luas efektif saat tegangan leleh, $\mathrm{N}_{\mathrm{c}}=$ kapasitas komponen struktur nominal dalam tekan $\left(A_{e n} f_{n}\right), A_{e n}=$ luas efektif saat tegangan kritis. 
Untuk penampang yang tersusun dari 2 profil dengan pengencang baut atau sekrup, rumus untuk rasio kelangsingan batang dimodifikasi berdasarkan rumus dari AISI S100-07 adalah:

$$
\left(\frac{\mathrm{K} \mathrm{L}}{\mathrm{r}}\right)_{\mathrm{m}}=\sqrt{\left(\frac{\mathrm{KL}}{\mathrm{r}}\right)_{\mathrm{o}}^{2}+\left(\frac{\mathrm{a}}{\mathrm{r}_{\mathrm{i}}}\right)}
$$

dimana $(\mathrm{KL} / \mathrm{r})_{\mathrm{o}}=$ rasio kelangsingan dari keseluruhan penampang tersusun, $\mathrm{a}=$ jarak sambungan, $\mathrm{r}_{\mathrm{i}}=$ radius girasi minimum yang tidak direduksi dari profil individu dari penampang tersusun.

$$
\begin{gathered}
\mathrm{f}_{e}=\frac{\pi^{2} \mathrm{E}}{(\mathrm{K} \mathrm{L} / \mathrm{r})_{\mathrm{m}}^{2}} \\
\lambda_{\mathrm{c}}=\sqrt{\frac{\mathrm{f}_{\mathrm{y}}}{\mathrm{f}_{e}}} \\
\mathrm{f}_{\mathrm{n}}=\left(0,658^{\lambda_{\mathrm{c}}{ }^{2}}\right) \mathrm{f}_{\mathrm{y}}
\end{gathered}
$$

\section{METODE PENELITIAN}

Metode Elemen Hingga atau yang biasa dikenal dengan istilah Finite Element Method (FEM) adalah metode untuk menyelesaikan permasalahan teknik dengan analisis numerik dan matematis. Beberapa contoh masalah yang dapat diselesaikan dengan metode elemen hingga antara lain analisis struktur, perpindahan panas, perpindahan massa, dan elektromagnetik. Metode penyelesaian dalam analisis ini dapat meliputi perpindahan titik (nodes displacement) yang selanjutnya dapat digunakan untuk mendapatkan nilai-nilai lain seperti tegangan (stress), atau regangan (strain).

Prinsip kerja metode elemen hingga adalah mendiskritisasi atau memecah sebuah elemen menjadi elemen-elemen kecil dengan besaran tertentu (elemen hingga) yang dihubungkan oleh titik-titik (nodes) yang dijadikan batas-batas untuk elemen tersebut. Proses diskrititasi elemen ini biasanya juga dikenal dengan istilah meshing. Pengerjaan dengan metode elemen hingga ini memecah elemen secara menyeluruh, melainkan dengan membuat formulasi persamaan masing-masing elemen hingga dan menggabungkannya untuk memperoleh solusi untuk elemen struktur tersebut. Singkatnya, solusi dari permasalahan struktur yang dimaksud adalah menghitung besarnya perpindahan dan tegangan yang dialami struktur akibat adanya beban yang bekerja (Logan, 2011).

\section{Pemodelan struktur dengan program MIDAS FEA}

Profil yang diuji pada penelitian ini memiliki mutu tegangan leleh (Fy) $280 \mathrm{MPa}$ dan tegangan ultimate (Fu) 360 MPa dengan batas elongation 18\%. Tinggi benda uji adalah $2950 \mathrm{~mm}$, dan penampang digabungkan dengan pemodelan sekrup untuk setiap jarak $725 \mathrm{~mm}$.
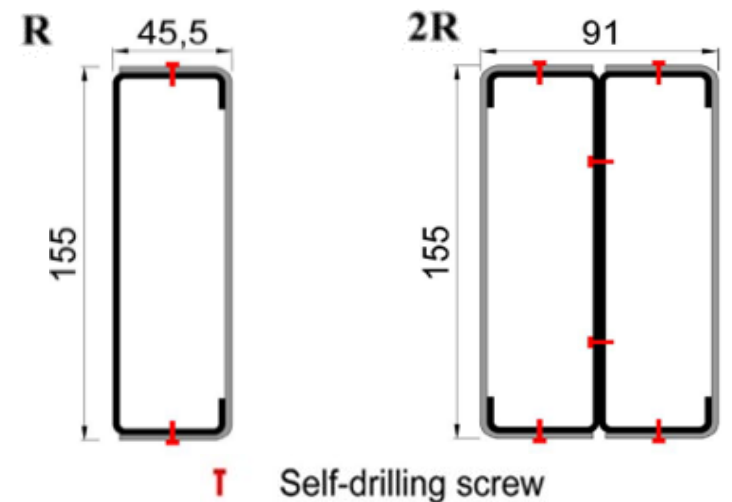

T Self-drilling screw

Gambar 3. Bentuk profil penampang R dan 2R (Sumber: Rodrigues dkk, 2016) 


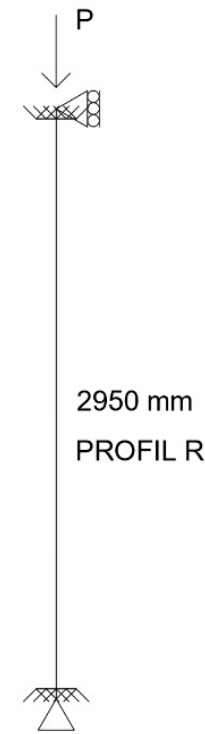

MODEL 1

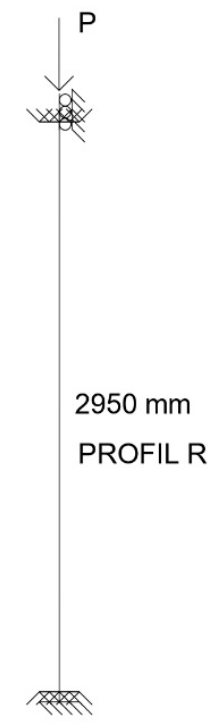

MODEL 2

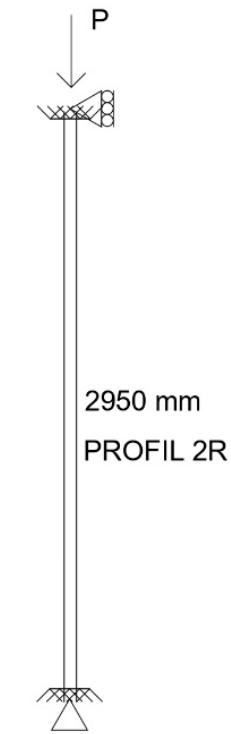

MODEL 3

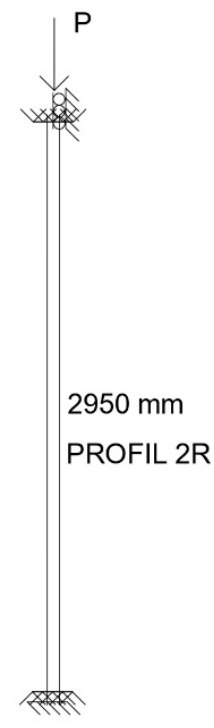

MODEL 4

Gambar 4. Sketsa sederhana model struktur

Berikut adalah langkah dalam pemodelan struktur dengan program MIDAS FEA

\section{1) Geometry}

Pada bagian ini dilakukan pembuatan profil penampang sesuai profil yang diinginkan dengan menggunakan line, setelah itu input panjang elemen dengan melakukan Extrude ke arah z sebasar $2950 \mathrm{~mm}$. Selanjutnya buat lubang untuk memodelkan sambungan baut. Setelah itu pilih Translate $>$ Copy dan buat Plane Face sesuai dengan ukuran baut untuk penentuan lokasi lubang dengan menggunakan perintah Geometry $>$ Boolean Operation $>$ Cut.

\section{2) Material}

Pada langkah ini dimodelkan material dari penampang tersebut. Memilih menu Analysis $>$ Material $>$ Create dengan memasukan data yang ada pada tabel 2.

Tabel 2. Data Material

\begin{tabular}{cc}
\hline Data & Nilai \\
\hline ID & 1 \\
Name & Steel \\
Elastic Modulus & $200000 \mathrm{Mpa}$ \\
Poisson's Ratio & 0,3 \\
Weight Density & $0,000077 \mathrm{~N} / \mathrm{mm}^{3}$ \\
Tipe Kegagalan & Von Mises \\
Plastic Strain & $0 ; 0,18$ \\
Tegangan Leleh & $280 \mathrm{Mpa}$ \\
Tegangan Putus & $360 \mathrm{Mpa}$
\end{tabular}

\section{3) Property}

Selanjutnya untuk memodelkan tebal dari material digunakan menu Property. Digunakan Property $>$ Create 2D dengan memasukan tebal profil sebesar 2,5 mm pada kolom T1. Setelah itu membuat Property $>$ Other $>$ Rigid Link dan pilih Rigid Body. Selanjutnya untuk memodelkan baut digunakan Property $>$ Create $1 \mathrm{D}>$ Line element lalu memilih Section template $>$ Solid round $>$ diameter $6.3 \mathrm{~mm}$. 

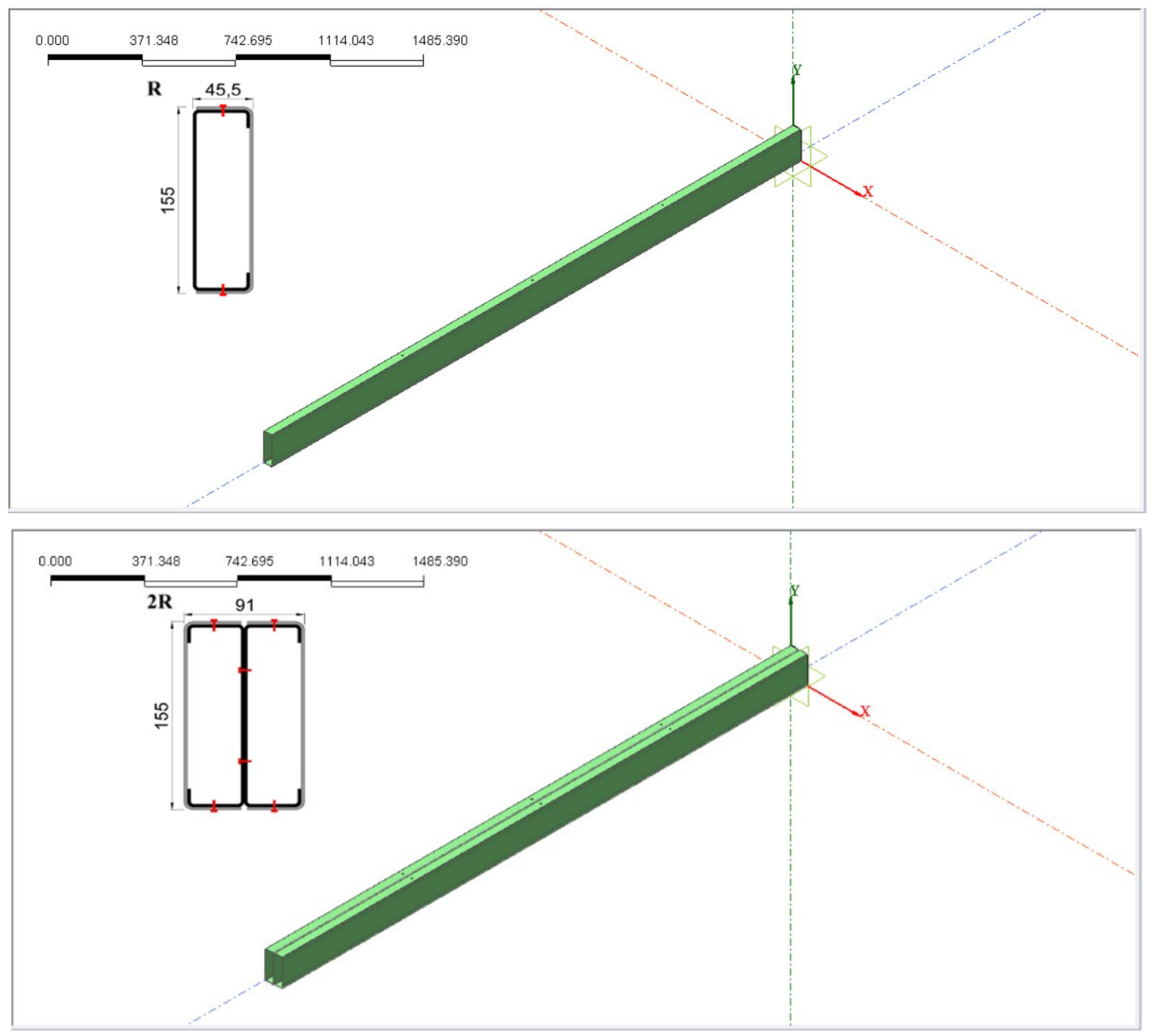

Gambar 5. Tampak pemodelan penampang

\section{4) Mesh}

Setelah itu dilakukan dikritisasi pada model dengan memilih Mesh $>$ Automesh $>$ Face dan pilih profil yang akan di Meshing setelah itu masukan Element Size sebesar $15 \mathrm{~mm}$. Jika memungkinkan diharapkan penggunaan meshing yang lebih kecil untuk mendapatkan nilai dengan keakuratan yang lebih tinggi.

\section{5) Reference Point}

Pada bagian ini dimasukan titik berat penampang dengan membuat node pada penampang. Pada bagian ini dipilih Mesh $>$ Create node dan dimasukan berturut-turut sesuai arah $\mathrm{x}, \mathrm{y}, \mathrm{z}$ sesuai dengan titik berat penampang tersusun. Setelah itu untuk menggabungkan nodal di ujung-ujung dengan titik berat dilakukan Mesh $>$ Element $>$ Create Link. 
Analisis Pengaruh Bentuk Profil Tersusun terhadap Gaya

Tekan pada Baja Canai Dingin Dengan Metode Elemen

Hingga
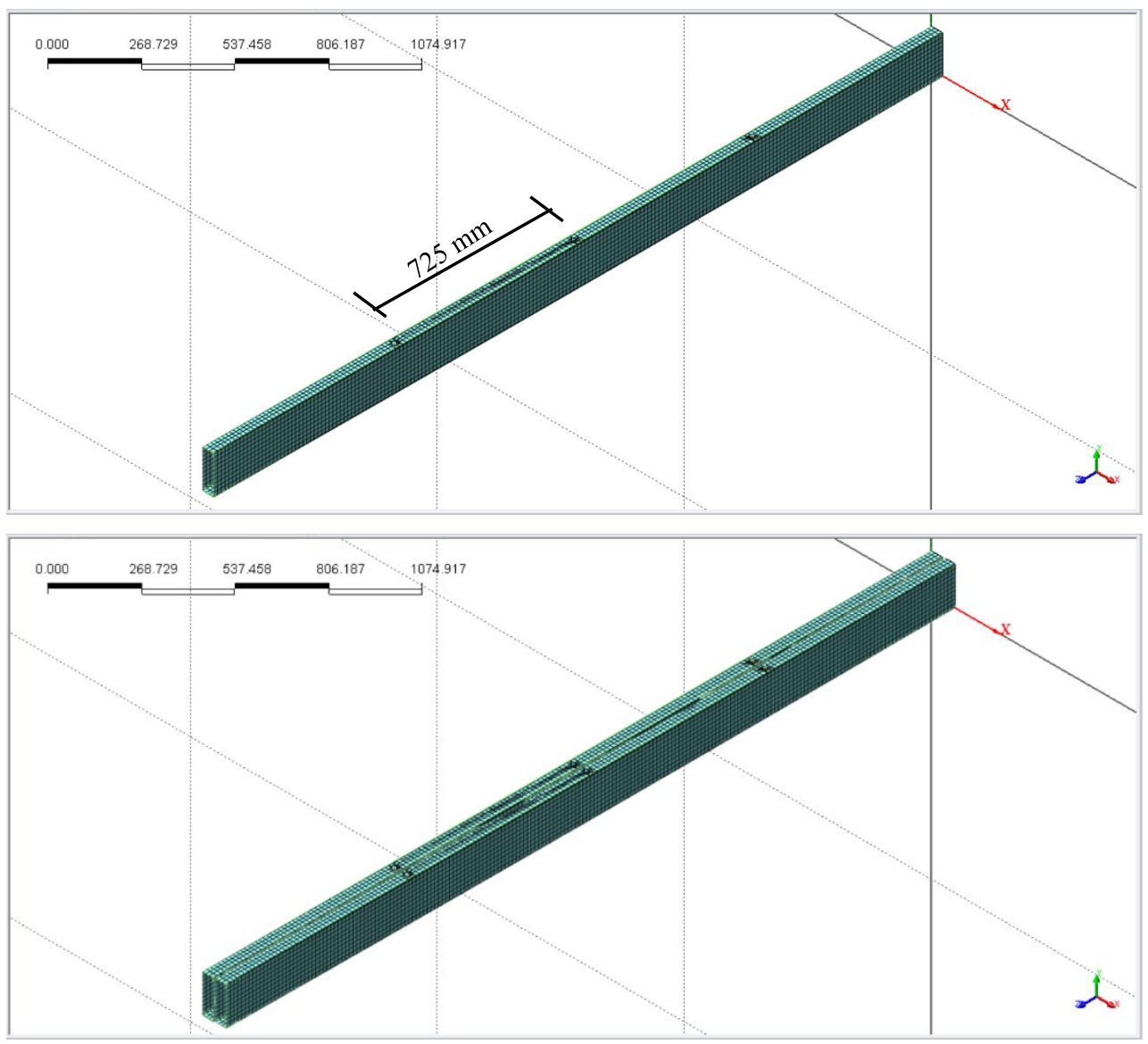

Gambar 6. Tampak Meshing

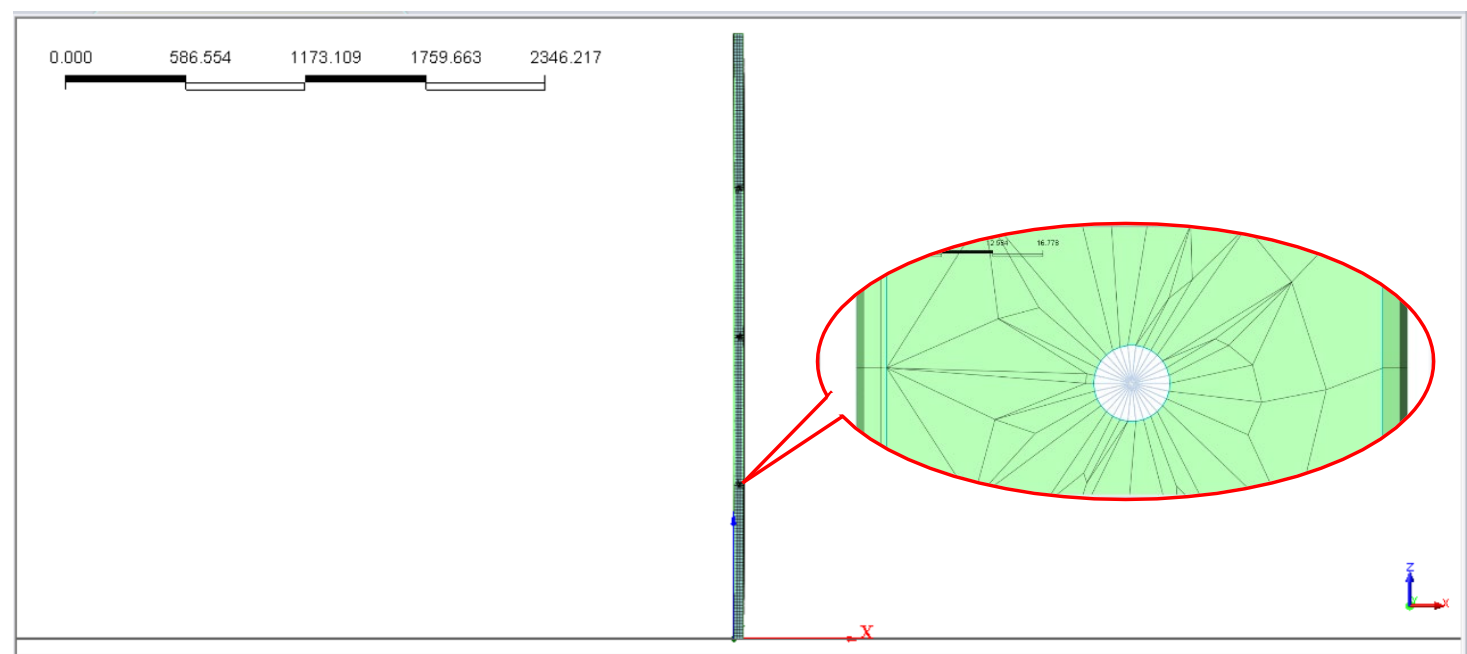

Gambar 7. Tampak Meshing Lubang 


\section{Boundary Condition}

Pada bagian ini dibuat perletakan Sendi - Rol yaitu pada kedua ujung Node yang telah dibuat sebelumnya dimana Sendi menahan Tx, Ty, Tz, Rz dan sisi satu nya sebagai Rol menahan Tx, Ty, Rz. Untuk peletakan Jepit-Jepit Rol pada kedua ujung Node jepit menahan Tx, Ty, Tz, Rx, Ry, Rz dan sisi satunya jepit rol menahan Tx, Ty, Rx, Ry, Rz.

\section{7) Load}

Pada bagian ini dimasukan beban berupa Force secara aksial dengan beban sebesar -1 N pada F3 yang menyatakan beban 1 satuan sejajar sumbu z pada Node titik berat yang telah dibuat sebelumnya.

\section{8) Analysis Case}

Setelah itu untuk melakukan analisis dibuat dahulu Analysis $>$ Analysis Case $>$ Add. Analysis Type yang digunakan Linear Buckling dengan tujuan untuk mengetahui Eigen Value dari model tersebut. Setelah mendapatkan Eigen Value langkah selanjutnya Post > Linear Buckling Analysis > Update Model with Imperfection sesuai mode yang telah ditentukan yaitu mode 1. Selanjutnya Analysis Type diubah menjadi Nonlinear Static dengan mengubah Load sesuai dengan Eigen Value yang didapatkan dari hasil analisis Linear Buckling.

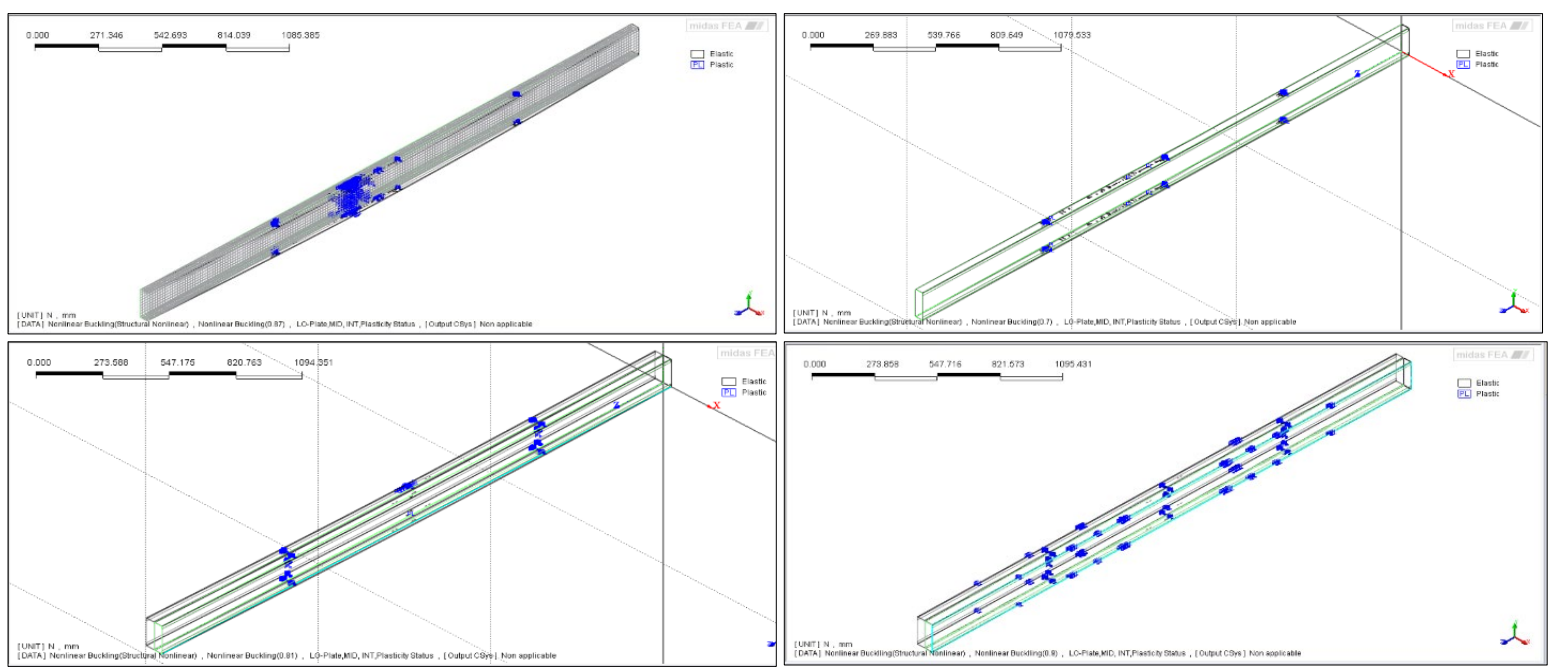

Gambar 8. Bentuk displacement FEA model 1 (kiri atas), model 2 (kanan atas), model 3(kiri bawah), model 4 (kanan bawah)

\section{HASIL DAN PEMBAHASAN}

Tabel 3. Perbandingan hasil kapastitas gaya aksial dengan FEA terhadap percobaan oleh Rodrigues et. al.

\begin{tabular}{cccc}
\hline Model & $\begin{array}{c}\text { Teori AISI S100-07 } \\
\text { Rodrigues et. al (2016) } \\
\mathrm{kN}\end{array}$ & $\begin{array}{c}\text { Rata-rata Percobaan } \\
\text { Rodrigues et. al (2016) }\end{array}$ & $\begin{array}{c}\text { \% perbedaan } \\
\text { Teori vs } \\
\text { Percobaan } \\
\%\end{array}$ \\
\hline Model 1 & 69,9 & $\mathrm{kN}$ & 0,16 \\
Model 2 & 176,5 & 70,01 & 15,58 \\
Model 3 & 287,6 & 149,01 & 11,73 \\
Model 4 & 430,9 & 253,87 & 13,11 \\
\hline
\end{tabular}


Analisis Pengaruh Bentuk Profil Tersusun terhadap Gaya

Dero Andika, et al.

Tekan pada Baja Canai Dingin Dengan Metode Elemen

Hingga

Tabel 4. Perbandingan hasil kapastitas gaya aksial dengan FEA terhadap AISI S100-07

\begin{tabular}{cccc}
\hline Model & $\begin{array}{c}\text { Teori AISI S100-07 } \\
\text { Rodrigues et. al (2016) } \\
\mathrm{kN}\end{array}$ & FEA & $\begin{array}{c}\text { \% perbedaan } \\
\text { Teori vs FEA } \\
\%\end{array}$ \\
\hline Model 1 & 69,9 & $\mathrm{kN}$ & 24,46 \\
Model 2 & 176,5 & 87,00 & 9,46 \\
Model 3 & 287,6 & 193,20 & 18,85 \\
Model 4 & 430,9 & 341,82 & 10,90 \\
\hline
\end{tabular}

Berdasarkan hasil perhitungan dengan FEA pengaruh dari peletakan terhadap kekuatan tekan nominal penampang cukup signifikan. Pada penampang $\mathrm{R}$ dengan ujung sendi-rol didapatkan hasil sebesar $87,00 \mathrm{kN}$ sedangkan penampang $\mathrm{R}$ dengan ujung jepit-jepit rol didaptkan hasil sebesar 193,20 kN. Penambahan kekuatan tekan yang dapat ditahan sebesar 106,20 kN. Sedangkan untuk penampang 2R dengan peletakan sendi-rol nilai kekuatan tekan nominal yang didapat bernilai 341,82 kN dan untuk penampang 2R dengan peletakan jepit-jepit rol nilai kekuatan tekan yang didapat sebesar $477,90 \mathrm{kN}$. Kekuatan tekan nominal pada penampang $2 \mathrm{R}$ jepit-jepit rol bertambah sebesar 136,08 kN dibandingkan dengan sendi-rol.

Dari tabel 3 dan tabel 4 dapat dilihat \% perbedaan antara hasil percobaan laboratorium yang sudah dilakukan oleh Rodrigues et. al. terhadap hasil perhitungan teoritis menggunakan AISI S100-07 dan hasil analisis dengan menggunakan program MIDAS FEA dengan hasil perhitungan teoritis AISI S100-07. Jika dibandingkan hasil percobaan di laboratorium untuk Model 1 dan Model 3 lebih mendekati hasil perhitungan teoritis menggunakan AISI S100-07 dibandingkan dengan hasil analisis dengan program MIDAS FEA terhadap hasil perhitungan teoritis. Sedangkan untuk Model 2 dan Model 4, hasil analisis menggunakan program MIDAS FEA lebih mendekati hasil perhitungan teoritis AISI S100-07. Hal ini dapat dilihat dari tabel 3 dan tabel 4 dimana \% perbedaan untuk Model 1 dan Model 3 lebih kecil pada pada tabel 3 dan \% perbedaan untuk Model 2 dan Model 4 lebih kecil pada tabel 4.

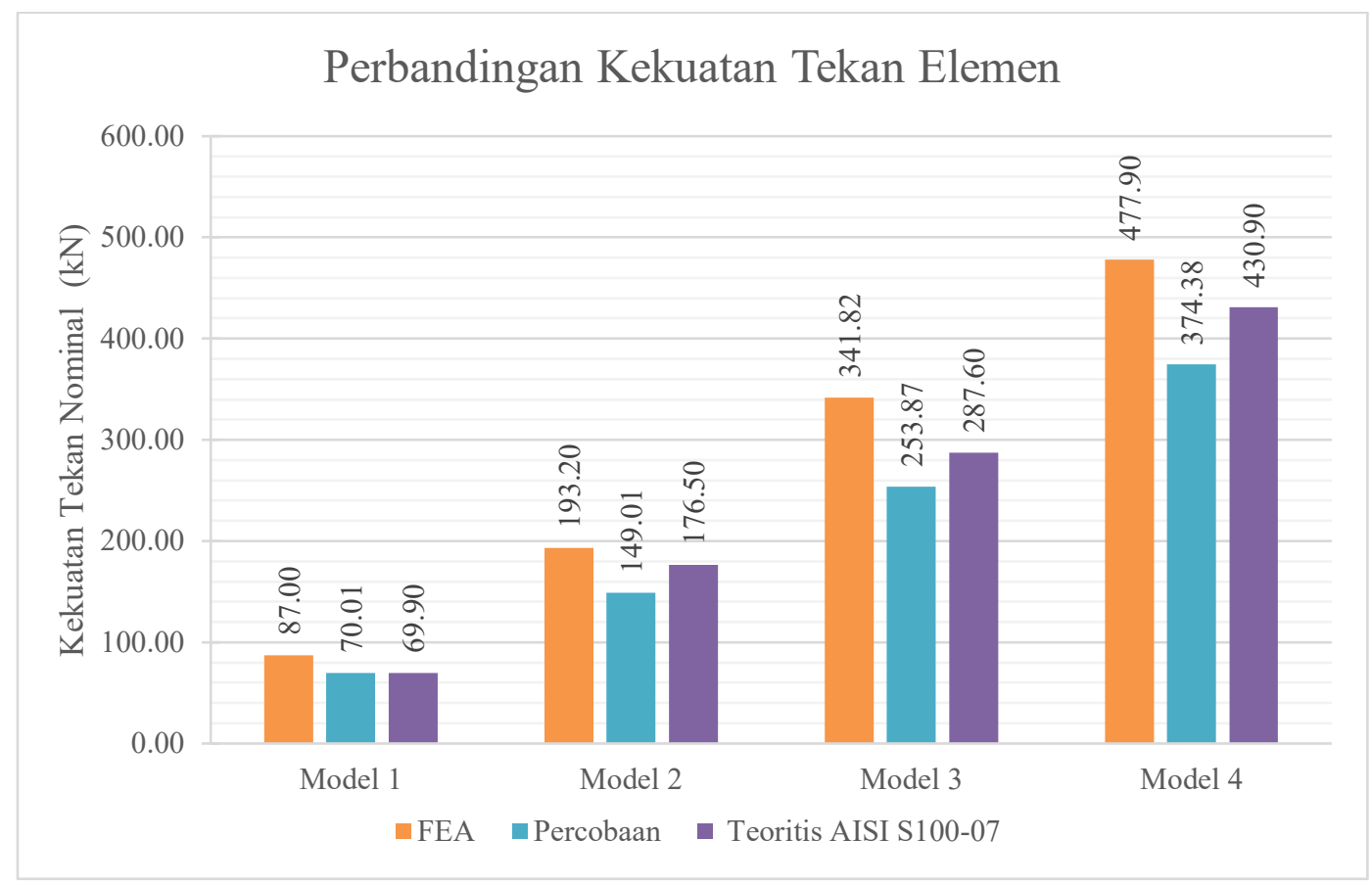

Gambar 9. Perbandingan FEA dengan percobaan dan AISI S100-07

Berdasarkan hasil analisis pada grafik diatas menunjukan bahwa nilai kuat tekan elemen dengan FEA, percobaan dan teoritis memiliki kecenderungan yang sama. Dari hasil analisis dengan FEA nilai kuat tekan nominal terbesar didapat pada elemen 2R dengan kedua ujung jepit-jepit rol. Nilai kuat tekan nominal yang didapat dari hasil FEA 
adalah sebesar 477,90 kN. Dari tabel 4 dapat dilihat bahwa hasil perhitungan dengan FEA menghasilkan perhitungan rata-rata 21\% lebih tinggi dibandingkan dengan perhitungan dengan AISI S100-07 untuk kedua ujung sendi-rol. Sedangkan untuk kedua ujung jepit-jepit rol perhitungan dengan FEA menghasilkan hasil rata rata 9,6\% lebih tinggi dibandingkan dengan perhitungan dengan AISI S100-07. Sedangkan untuk perhitungan FEA menghasilkan perhitungan rata-rata $29 \%$ lebih besar dibandingkan dengan percobaan yang sudah dilakukan oleh Rodrigues, dkk. pada tahun 2016. Perbedaan yang didapat dari hasil analisis FEA terhadap teoritis dikarenakan masih kurangnya implementasi syarat batas untuk menggambarkan keadaan sendi pada kedua ujung batang. Karena pada FEA pemodelan menggunakan tiga dimensi sedangkan secara teoritis pemodelan hanya dianggap dua dimensi.

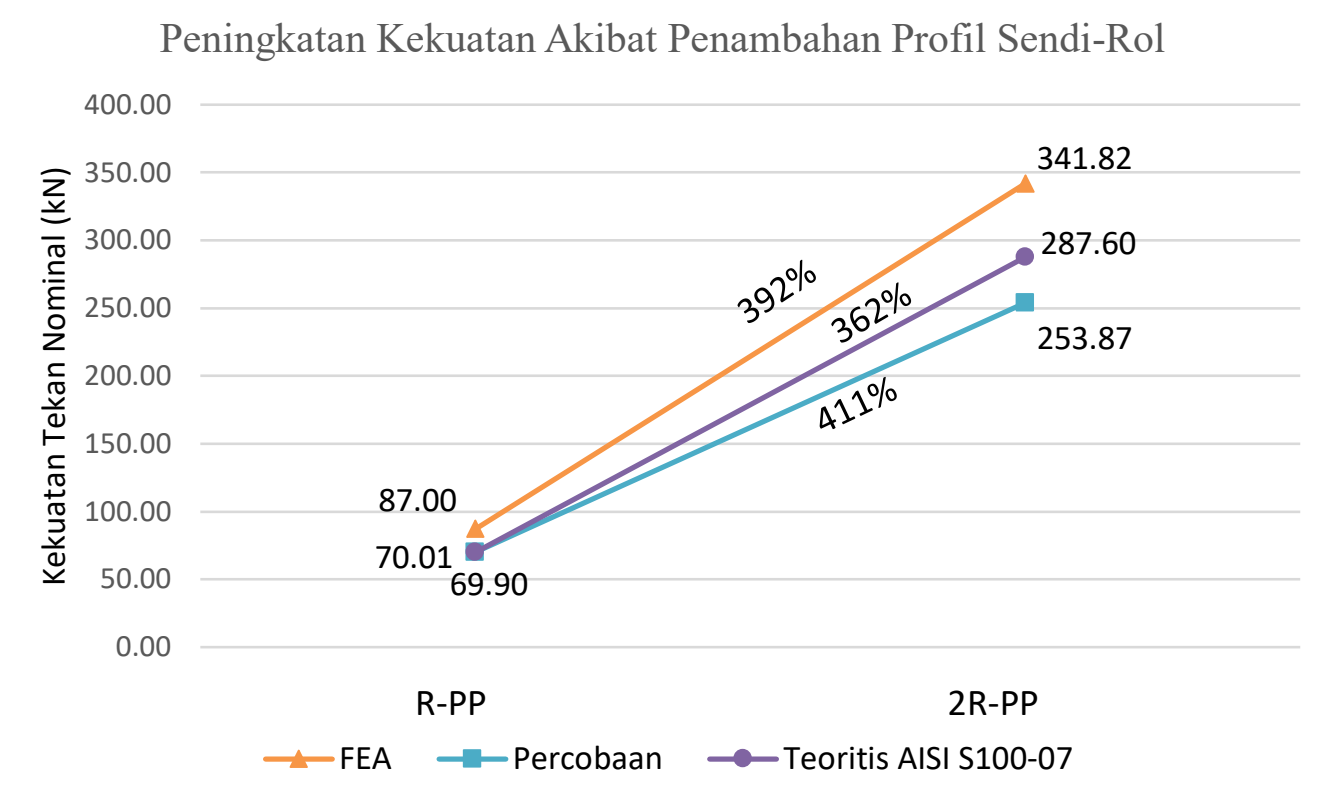

Gambar 10. Grafik pengaruh penambahan profil terhadap kekuatan tekan nominal sendi-rol

\section{Peningkatan Kekuatan Akibat Penambahan Profil Jepit-Jepit Rol}

600.00

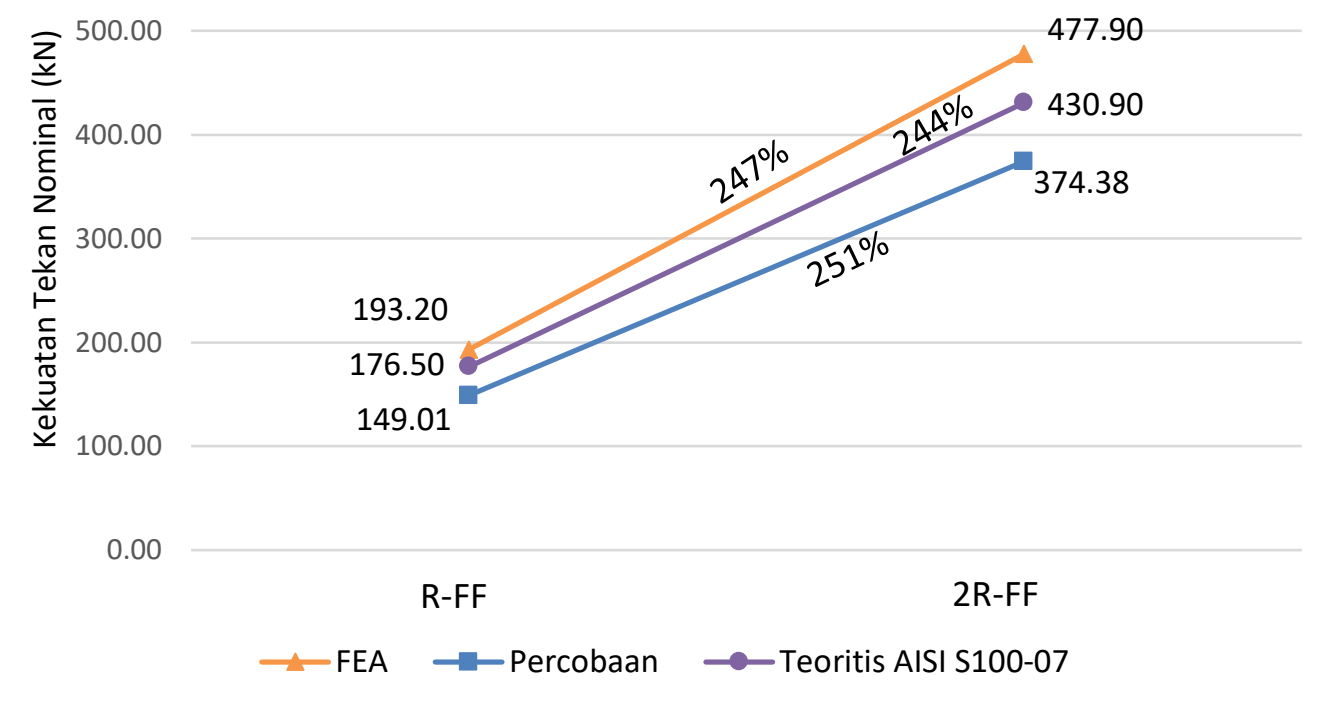

Gambar 11. Grafik pengaruh penambahan profil terhadap kekuatan tekan nominal jepit-jepit rol 
Pada gambar 10 dan 11 dapat dilihat persentase kenaikna kekuatan tekan nominal dengan variasi penampang R dan 2R. Pada gambar 10 peletakan yang dimodelkan adalah peletakan sendi-rol dan dapat dilihat bahwa kapasitas batang untuk menahan gaya tekan nominal bertambah sekitar 360\% pada peletakan sendi-rol. Sedangkan untuk gambar 11 peletakan yang dimodelkan adalah peletakan jepit-jepit rol dan dapat dilihat perubahan penampang dari profil $\mathrm{R}$ ke 2R memberikan perubahan kapasitas tekan sebesar 240\%. Grafik 10 dan 11 memberikan trend yang sama untuk percobaan, MIDAS FEA, dan teori AISI S100-07 sehingga pemodelan menggunakan MIDAS FEA sudah menunjukan ketepatan dari pemodelannya.

\section{KESIMPULAN DAN SARAN}

\section{Kesimpulan}

Berdasarkan analisis yang sudah dilakukan baik secara numerik menggunakan Metode Elemen Hingga dengan bantuan program MIDAS FEA, maka dapat diambil beberapa kesimpulan sebagai berikut:

1. Perhitungan analisis numerik menggunakan FEA menghasilkan nilai yang lebih besar jika dibandingkan dengan hasil percobaan yang pernah dilakukan dan juga hasil perhitungan teoritis.

2. Hasil analisis dengan program MIDAS FEA memberikan hasil lebih mendekati perhitungan teoritis dengan AISI S100-07 pada peletakan jepit-jepit rol sedangkan hasil percobaan di laboratorium memberikan hasil yang lebih mendekati perhitungan teoritis dengan AISI S100-07 pada peletakan sendi-rol.

3. Peletekan jepit-jepit rol menghasilkan kekuatan tekan nominal yang lebih besar pada setiap model penampang yang dianalisis. Untuk penampang R peletakan jepit-jepit rol menghasilkan kekuatan $213 \%$ lebih besar dari peletakan sendi-rol, sedangkan untuk penampang 2R peletakan jepit-jepit rol menghasilkan kekuatan 147\% lebih besar dari peletakan sendi-rol.

4. Perubahan profil dari $\mathrm{R}$ menjadi $2 \mathrm{R}$ memberikan kekuatan tekan nominal yang jauh lebih besar jika dibandingkan dengan merubah peletakan dari sendi-rol menjadi jepit-jepit rol. Penambahan profil dari $\mathrm{R}$ menjadi 2R menghasilkan kekuatan tekan nomimal 392\% lebih tinggi untuk peletakan sendi-rol dan $247 \%$ lebih tinggi untuk peletakan jepit-jepit rol.

\section{DAFTAR PUSTAKA}

American Iron and Steel Institue. North American Specification for the Design of Cold-Formed Steel Structural Members. Mexico: AISI, 2007.

Badan Standardisasi Nasional. Struktur Baja Canai Dingin (SNI 7971:2013). Jakarta: BSN, 2013.

Dewobroto, Wiryanto. "Struktur Baja Perilaku, Analisis \& Desain edisi 2." Dewobroto, Wiryanto. Struktur Baja Perilaku, Analisis \& Desain edisi 2. Jakarta: Lumina Press, 2015. 4.

Li, Yuanqi, et al. "Ultimate Load-Carrying Capacity of Cold-Formed Thin-Walled Columns with Built-up Box and I Section under Axial Compression.” Thin-Walled Structures, 2014, doi:10.1016/j.tws.2014.02.003.

Logan, Daryl L. A first Course in the Finite Element Method, FifthEdition. Canada: Nelson, 2011.

Rodrigues., et al. "Buckling Resistance of Axially Loaded Cold-Formed Steel Columns." Thin-Walled Structures, 2016, doi:10.1016/j.tws.2016.05.010.

Yu, Wei Wen, and Roger A. LaBoube. "Cold-Formed Steel Design: Fourth Edition.” Cold-Formed Steel Design: Fourth Edition, 2010, doi:10.1002/9780470949825. 